\title{
Closed-loop Supply Chain as an Agent of Sustainable Development
}

\author{
Shu-San Gan ${ }^{1 *}$
}

\begin{abstract}
Sustainability has recently become an important issue which received growing attentions from government, society, industries as well as academia. There have been concerns on relatively rapid growth in population and increased quality of life despite limited natural resources and landfill capacity. Closed-loop Supply Chain (CLSC) is one of many approaches to mitigate the abovementioned disproportion. This article aims to study closed-loop supply chain by explaining the definition, description, pros and contras, relevance, case studies from literature, and potential research; such that its role as an agent of sustainable development can be recognized.
\end{abstract}

Keywords: Closed-loop supply chain, sustainable development, recovery process, remanufacturing, product return management.

\section{Introduction}

Sustainability has become an important issue since the world came to realize the threats to the survival of our planet. Data on the United Nations world population prospects (WPP [1]) revealed there is a significant increase in the past 60 years, as showed in Figure 1. With higher population, more resources should be consumed and more waste produced. Also, there would be more processes that could be harmful to the environment.

Gradel and Allenby [2] proposed a master equation which showed that environmental impact is influenced by population, lifestyle (presented by GDP per person) and degree of environmental impact per unit of per capita GDP. Therefore the increasing world population, as the first factor, would increase environmental impact. As for the second factor, the trend of GDP is also increasing (Figure 2, CIA [3]), which represent higher effort to improve quality of life. This condition is usually followed by activities that requires resources and produces waste, such as the use of tissue paper rather than towel or handkerchief, the use of disposable products as a result of busy living and practicality. The third factor, the technology term, presents opportunities to control environmental impacts by exploring new technologies for industrial activities that can be implemented with minimum environment consequences.

Kaebernick et al. [4] proposed that the third factor can be presented as the reciprocal of eco-efficiency.

\footnotetext{
1 Faculty of Industrial Technology, Mechanical Engineering Department, Petra Christian University. Jl. Siwalankerto 121-131, Surabaya 60236. Email: gshusan@petra.ac.id

* Corresponding author
}

Thus, increasing eco-efficiency will reduce technology term and consequently lower total environment impact. Two major areas of activities in product life cycle were proposed to improve eco-efficiency, namely at design stage and at the EOL (end-of-life) by implementing reuse, recycle, remanufacture.

Our planet has limited natural resources and limited landfill. During industrial evolution, natural resources were utilized as if their availability were unlimited. This was a typical case of type I of the interactions between industry and society with natural systems where "unlimited resources, unlimited waste" principal is applied (Gradel and Allenby [2]). The amount of resources were so large compared to the user. For example, excessive wood logging in Papua has reduced the forest area from 42 million hectare in 2009 to 30.07 million ha. in 2011 (Tawaru [5]). Another example is deforestation in Mount Pangrango (Humas-UGM [6]) has led to serious flood in Jakarta, according to Universitas Gajah Mada discussion forum in 2011. Also, the Tempo nesws reported that the Jakarta flood might be worsened by excessive waste disposal in Ciliwung River (Prihandoko [7]). When serious environmental issues had emerged, Industrial actors then were forced to switch to type II (Gradel and Allenby [2]), where energy and resources are considered limited, and limited waste should flow out of the system. There are some cycling loops due to the limited resources. For example the implementation of reuse, recycle and remanufacturing is an act of type II. However, in the long run, the sustainability is threatened since there still exists one direction flow. The best sustainable system is type III, where complete cycling loops occur. Within this system, waste of one component of the system can be resources of another, so resources and waste are fully cycling in the system. However, type III seems impossible to achieve, but striving to achieve it will lead toward more environmentally responsible processes. 


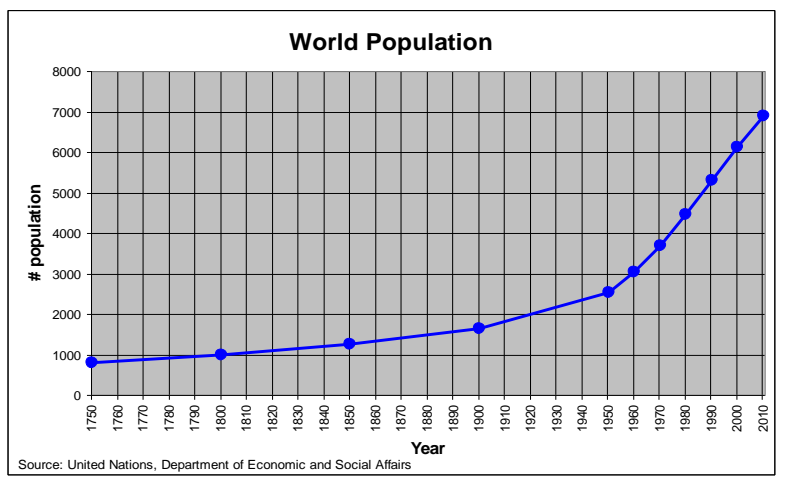

Figure 1. United Nations: World population

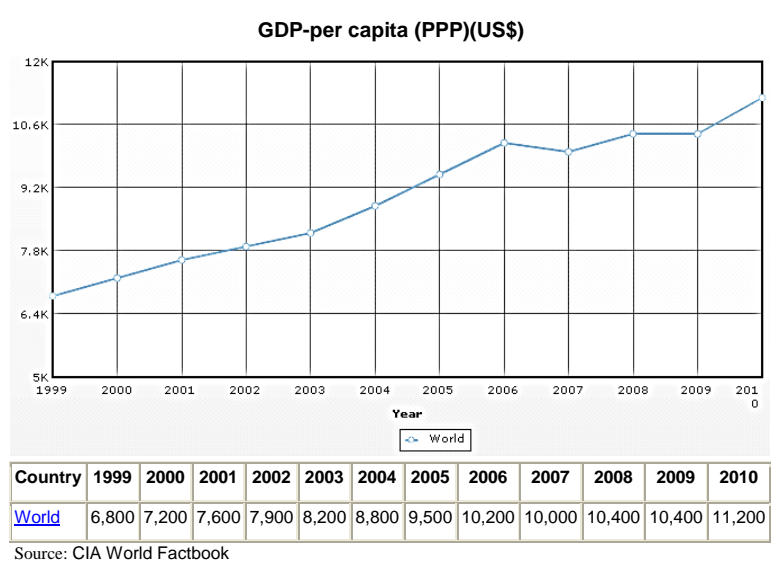

Figure 2. World's GDP per capita 1999 - 2010

In supply chain management, type II system can be applied by adding a reverse channel of supply chain into the traditional (forward) supply chain, in order to perform a cycling loop. Forward channel includes flow of raw material from supplier to manufacturer, after the production process completed, products are transported and distributed to retailers and finally in the hand of customers. Reverse channel of supply chain is started by collecing product returns that comes from various reasons, and then directed to inspection and selection, recovery processes (reuse, recycle and remanufacturing) and redistribution as well as marketing of the recovered products. Closedloop supply chain (CLSC) represents the integration of forward and reverse channel of supply chain, which actually is an effort to perform a cycling loops in industries.

\section{Methods}

\section{Sustainable Development}

"Our Common Future", or "the Brundtland Report" (WECD [8]), from the United Nations World Commission on Environment and Development (WCED) introduced the concept of sustainable development, i.e. "development that meets the needs of the present without compromising the ability of future generations to meet their own needs". There are two key concepts in it, which are (a) the human essential needs and (b) the limitations on the environment's abillity to meet present and future needs.

The concept of sustainable development can be summarized into several points, which are (1) Meeting the human basic needs and extending for better life, by improving productive potential and ensuring equitable opportunities for all. (2) Making sure the demographic developments are in harmony with the changing productive potential. (3) Promoting values to shape perceived needs that consider the ecological bounds. (4) Protecting the Earth natural systems, i.e. the atmosphere, the waters, the soils, and the living beings. (5) Renewable resources should be use within the rate of regeneration and natural growth. (6) The consumption of nonrenewable resources should consider their limited quantities, the technology for minimizing depletion, and the possibilities for substitutes. (7) Ensuring equitable access to constrained resources (energy, water, materials, land), and enhancing their capacities through technology. Also, the harmful impacts on their quality should be minimized. (8) Making sure the conservation of plant and animal species.

Therefore, the strategies outlined in the report are "reviving growth; changing the quality of growth; meeting essential needs for jobs, food, energy, water, and sanitation; ensuring a sustainable level of population; conserving and enhancing the resource base; reorienting technology and managing risk; and merging environment and economics in decision making".

In conclusion, the efforts to achieve sustainable development should be supported by several systems, i.e. political, economic, social, international, administrative system; and also two systems that are discussed in this paper i.e. producion and technology systems.

\section{Closed-loop Supply Chain}

As discussed earlier, closed loop supply chain (CLSC) is an effort to perform a cycling loop that lead to higher degree of sustainability. The implementation of CLSC could reduce landfill waste because there are attemps to use the wastes from one process as a resource for another process or even the same process. Recycling is an attempt to use wastes as raw material, reuse is applied when products at their end-of-use are reselled in the second market, while remanufacturing is an effort to reprocess used product or returns into as-good-as-new products. These activities also reduce natural resources consumption because less new raw material required. 
Furthermore, CLSC with remanufacturing could reduce energy consumption, because the product is not built from raw material but from a used product with the attached added-value. CLSC also offers better options to implement Extended Producer Responsibilities (EPR) where producers not only fulfill their obligation according to the regulations, but also could gain benefits from cost reductions that comes with CLSC recovery activities (Guide and van Wassenhove [9]).

\section{The Definitions of CLSC}

There are several definitions on Closed-loop Supply Chain. Blanc [10] claimed that closed-loop supply chain management is defined as the integration of business processes that creates additional value for all original and new players in the supply chain through the closure of goods flows from the point of consumption back into a supply chain. Lebreton [11] defined it as supply chains that simultaneously carrying both forward and reverse flows. However, we will use the definition given by Guide and Wassenhove [9]: "Closed-loop supply chain management is the design, control and operation of a system to maximize value creation over the entire lifecycle of a product with dynamic recovery of value from different types and volumes of returns over time".

\section{The Description}

According to Guide et al. [12], closed-loop supply chain includes supply chains that are designed to consider the processes required for used products or returns, in addition to the traditional forward processes. These additional processes (also referred to as the reverse supply chain) are Product acquisition or collection, refers to all activities for collecting used products and moving them physically for further treatment. Collection may include purchasing, transportation, and storage activities Inspection (test, sort) and disposition, denotes all operations determining whether a given product is re-usable and in which way. Thus, inspection and separation results in splitting the flow of used products according to a certain reuse option (and/or disposal option). Inspection and separation may include disassembly, shredding, testing, sorting and storage steps.

Recovery process or re-processing, where a used product is transformed into usable product or component, or material. This transformation may take different forms including recycling, repair and remanufacturing. In addition, activities such as cleaning, replacement and re-assembly may be involved.
Redistribution refers to directing re-usable products to a potential market and physically to moving them to future users. This may include sales, transportation and storage activities.

There are three primary activities in CLSC (Guide and van Wassenhove [9]): (1) Product Returns Management, which focused on timing, quantity and quality of returned products (including product acquisition management processes) (2) Remanufacturing Operational Issues, include reverse logistics, test, sort, and disposition activities, product disassembly, and remanufacturing processes. (3) Remanufactured Products Market Development, include remarketing activities, channel choice and coordination, and market cannibalization issues.

Supply Chain Management aims at the integration of traditional 'forward' supply chain processes. Krikke [13] considered the reverse supply chain as part of supply chain integration, thus contributing to lower overall costs and environmental impacts of the entire supply chain. CLSC's contribution in sustainability mostly comes from product returns recovery activities, since it helps to reduce the consumption of natural resources, reduce waste which in time will save landfill, and save energy as well as reduce green-house-gasses (GHG) emissions by reducing processes, compared to making new products

\section{The Pros and Cons}

In the CLSC implementation, there are arguments that support it, but there also some opinions are not in favor of CLSC.

Some benefits that were acknowledged are: Supporting sustainability development, which includes reducing raw material and natural resources consumption, waste reduction, and less emission from manufacturing processes. Recovery processes in CLSC use product returns as raw material hence the reduction, as mentioned in the background. Fuji Xerox Australia has experienced reduced resource consumption and waste generation by implementing remanufacturing (Kerr and Ryan [14]). Reuse, recycle and remanufacturing use fewer production process compared to producing new products from raw material (Kaebernick et al.[4]), therefore less greenhouse gasses emitted from manufacturing proceses.

Creating economic benefit, which comes from lower material cost, fewer manufacturing cost, and higher sales as a result of eco-customer valuation. Kaebernick et al. [4] showed that with reuse, recycling, and remanufacture, total costs can be 
reduced to an acceptable level and therefore increase the profit. The basic ideas are cost for reusing old product is less than making new product, remanufacture cost is less than production cost, and with reuse and remanufacture, the environmental cost is smaller. In IBM's spare-part management, reuse option has reduced procurement cost significantly (Fleischmann et al. [15]). For customers who are environmentally conscious, closed-loop supply chain is viewed as a pro-environment activities, so there are positive sentiments towards the products and could increase sales.

Triggering creativity and innovation in product design stage, to find new or modifying design such that product life can be extended, value of returns products can be recovered, and implementing DFE (Design for Environment). For example, LG designs green products, which considering resource reduction, hazardous substance free, recyclability improvement, energy efficiency enhancement, GHG emissions reductions, and living environment care (LG [16]).

Seitz [17] performed in-depth case studies within some remanufacturing facilities of a major European Vehicle Manufacturer, to assess motives for product recovery, and found that ethical/moral responsibility, legislation and direct profitability were not strong motives to decide for recovery process. Some of the opinions are: Sustainability is not the motive or driver for recovery of product returns. Statements obtained from Seitz's [17] inverviews showed that environmental consideration has nothing to do with the firms' remanufacturing efforts. The most important drivers for them are spare parts supply and warranty, because in some cases, a remanufactured engine is the only chance to provide replacement in a short timeframe.

Product returns uncertainty is high, because the returned cores can vary from pretty good condition, slightly damaged, to practically unusable. Since complex quality assessment would be too costly, the firms usually apply flat valuation.

Buyers' reluctance towards recovered products. Collection and inspection are additional costs Tracking used product is not an easy task. Customer behaviors in securing used product can vary significantly, so the quantity of product returns is difficult to predict.

Even though there are pros and cons toward the implementation of closed-loop supply chain, we find the recent developments in academic research are in favor of closed-loop supply chain, especially those that involve remanufacturing of electronic and electrical products. These products are the notorious contributors of hazardous wastes.

Several studies show that closed-loop supply chain with remanufacturing shows good potential for electronic products and mobile phones (Steinhilper, [18], Franke et al. [19], Tong [20], Chan and Chan [21], Rathore et al. [22], Wang et al. [23]). Several others show that it is profitable (Guide et al. [12], Xing et al. [24], Kwak and Kim [25]). Also, CLSC with remanufacturing is environmentally friendly, eco-efficient, and creating economic value (Nnorom and Osibanjo [26]; Neto and Bloemhof-Ruwaard [27], Nnorom and Osibanjo [28], Neto et al.[29] Neto and Bloemhof-Ruwaard [30]).

\section{How CLSC supports Sustainable Development?}

The Brundtland Report [8] shows that the achievement of sustainable development needs supports from several systems including production and technologycal system. A production system that supports sustainable developments is the one that values the responsibility to preserve the ecological balance. As for the technological system, it should encourage the continuous search for new and better solutions.

There are two out of seven strategies in Our Common Future that can be carried out by implementing closed-loop supply chain.

\section{Conserving and Enhancing the Resource Base}

It is imperative that the natural resource base should be conseved and enhanced, because of the current high industrial consumption worldwide alongside with the population growth. The industrial activities are mostly consuming natural resources and energy, and in the same time producing pollution and wastes. The availability of energy resources and the Earth's capacity to absorb the byproduct of the energy use would limit the global development. On the supply side, there are limitation to the energy resource which is shown by the depletion of oil reserves. On the by-product aspect, there are emissions problems that are manifested in pollution and global warming. Also, the industrial activities are producing wastes, which could endanger the sustainability due to the limited landfill.

\section{Reorienting Technology}

The basic idea of this strategy is reorientation of technology that links human and nature. Therefore, the capacity of technological innovation needs to be improved in the developing countries, such that the challenges in the sustainable development can be 
handled more effectively. Also, the orientation of technology needs to be changed in favor of environmental factors. Another important tasks are enhancing research, design and development in innovations in material technology, energy conservation, and information technology. While the traditional concept of technology is focusing on improving product and process for higher market value, it is time to shift the focus toward innovation that produce a 'social good', such as increased product life, low-waste, improved air quality, and less-pollution.

By definition, CLSC is an attempt to maximize value creation over the entire life-cycle, from returns. Remanufacturing is one of the recovery processes in CLSC that transform used products into like-new condition (Lund and Hauser [31]). Recycle is another recovery process that retreives the materials from used product or component for further reuse. Therefore, CLSC provides suports to the sustainable development in several ways

\section{Reducing the use of energy and mitigate emission problems.}

Since CLSC with remanufacturing work on used product, instead of from raw material, the manufacturing process needed is not as much as producing new product. Consequently, the less pollution released due to less production activities needed.

Gray and Charter [32] claim that remanufacturing can reduce production cost, the use of energy and materials. Neto and Bloemhof-Ruwaard [27] show that remanufacturing for mobile phones and personal computers substantially mitigates the energy used in the life cycle of these products. Nnorom and Osibanjo [28] find that remanufacturing can extend a product's life, improve the reusability of components, reroute waste and energy, and at the same time create economic value. Despite the fact that remanufactured products may need to be sold at lower prices, but the economic output per energy unit is still higher for remanufactured products. Neto and Bloemhof-Ruwaard [30] also find that remanufacturing significantly reduces the amount of energy used in the product life cycle, even though the effectiveness of remanufacturing is very sensitive to the life span of the second life of the product.

\section{Reducing the use of natural resources}

The output of CLSC is a product processed from a used or returned product. There is much less raw material needed in this process; raw material that could be originated from natural resources.
Sasikumar and Haq [33] conclude that battery recycling does not only protect the environment, but also save natural resources, energy, clean air and water, landfill space, money on raw materials.

\section{Mitigating the waste problems}

The supply of a CLSC reprocessing is used product or return. Instead of sending an end-of-life or end-ofuse product to the landfill, CLSC reprocesses and redistributed it to the market. This way, the product's life is extended, and less waste is sent to the landfill in the same timeframe.

Chung and Wee [34] study the inventory control system in a CLSC. They consider cost-components that drive the reduction of waste and energy. Guide and Wassenhove [35] show that product acquisition under waste-stream could reduce the waste sent to the landfill. Similar argument is brought by Nnorom and Osibanjo [26], Jo, et al. [36], Hsueh [37], and Sasikumar and Haq [33].

\section{Supporting technology with environmental orientation}

The concept of CLSC is driven by the concern to the environment. The development of CLSC is always followed by the innovation using technologies that could improve the performance of CLSC.

\section{Results and Discussions}

\section{Case Studies from the Literature}

\section{Case I: Xerox Copier in Australia (Kerr and Ryan [15])}

Xerox has implemented recovery of used copier since the 1960s. However, the more formal remanufacturing system is not developed until late 1980s and early 1990 s, with a goal to maximize the profitability of remanufacturing operations. Currently, Xerox runs remanufacturing programs for used photocopiers, and printers, toner cartridges, globally. Kerr and Ryan [14] conducted a study to evaluate whether the remanufacturing system could reduct the total resource consumption and waste generation. The study is conducted by following the life cycle of a product under a well-established remanufacturing system, in order to gather data that later will be used to make a rigorous assessment of the contribution in reducing waste and resource consumption.

A comparison was made, between the life cycles of remanufactured and non-remanufactured Xerox machines in Australia, using a quantitative assess- 
ment. For each coppier, it was assumed that there are 12 million copies made over a maximum period of ten years within each life cycle.

The life cycles were compared based on five parameters which are raw materials consumption $(\mathrm{kg})$, energy consumption (MJ), greenhouse gas emissions ( $\mathrm{kg}$ of $\mathrm{CO} 2 \mathrm{eq}$ ), water consumption (ltr), and waste going to landfill $(\mathrm{kg})$. The study found that remanufacturing can reduce resources consumption and waste generation over the life cycle, up to 3 times. The greatest reductions is found on a product that is designed for disassembly and remanufacturing.

\section{Case II: IBM Spare-parts Management (Fleisch- mann et al. [14])}

As a response to the increased significance in closedloop supply chain, especially in electronic industry, IBM created a business unit called Global Asset Recovery Services (GARS) in 1998, to manage product returns worldwide. The goal is to determine the best disposition of returned product such that the value recovered can be maximized. There are 25 GARS facilities in the world, and the tasks are collecting, inspecting, and assigning returns to appropriate recovery options. IBM has identified that dismantling is potential for large savings. Disassembling a returned item for extracting a part is not expensive. The significant costs are for thorough testing to make sure that all parts entering the service network meet quality standards. These costs are generally much lower than those for buying a new part, which can reach 80 percent lower.

The problems identified are ad-hoc dismantling policy became inadequate as volumes got higher, the existing information technology system could not support the systematic exploitation, and the policy suffered from a lack of communication and coordination between the dismantling operation and parts planning. Therefore, a project was created to establish systematic dismantling, and the objectives are (1) designing the dismantling channel, (2) selecting parts to be retrieved from a given machine, (3) coordinating dismantling with the other sources of parts. The methodology for this project is: Define the processes applied to each part type from a returned machine, to be considered reusable. The general steps are disassembly, testing, and possible repair or upgrading.

Specify which parts to disassemble when a returned machine arrives: determine channel design be push or pull, identify trade-off between immediate costs and expected future savings, specify a maximum expected time in stock, or equivalently, a maximum stock level beyond which the firm will dispose of parts, according to the method discussed in Fleischmann et al. [14].

Analyze alternative reactive and proactive coordination strategies, supposing that the corresponding information was available. There are three alternative policies considered, i.e. optimal basestock level, reactive policy that does not take the dismantling coverage into account in determining the base-stock target, and netting policy that reduces the target level of the case without dismantling by the expected dismantling supply during the order lead time plus review period. There also exists uncertainty of dismantling parts availability that need to be considered, as well as the assessment of the potential benefit of more reliable forecasts of returns.

Model and simulation, includes basic inventorycontrol model with product returns, which will be solved analytically, and simulation model that captures more details of the problem.

The outcome of the analytic model gives the average inventory and back order costs, as a function of the dismantling coverage, with three alternative order policies. It shows that a reactive policy requires high stock levels, and a netting rule is close to optimal.

The results of the simulation model shows the difference of the total costs (procurement costs plus inventory-related costs) without dismantling and with dismantling, as depicted in Figure 3. The procurement costs are the same for all strategies with dismantling. The leftmost column is the case without dismantling. The other column correspond to six alternative strategies for integrating the dismantling source, based on push or pull design, and three alternative coordination mechanism (reactive, netting, and optimal). The results show that the savings in procurement cost due to dismantling are much higher than the potential increase in inventory-related costs. Also, the cost coordination strategy is higher than the channel design.

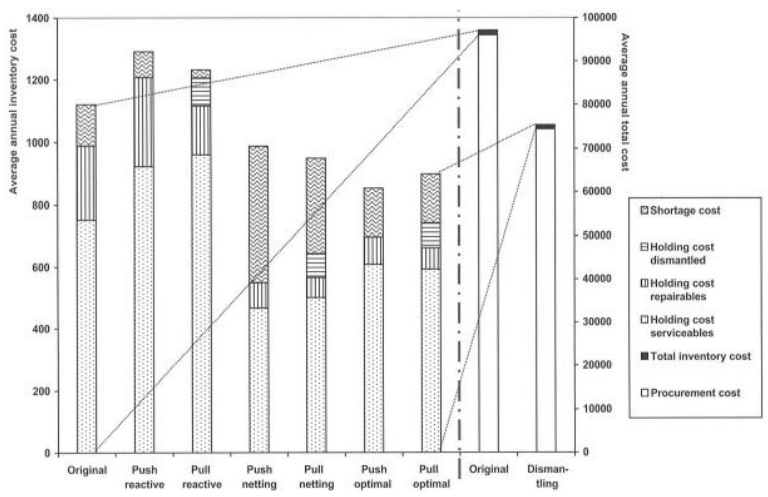

Figure 3. The results of the simulation model, average inventory cost for three strategies and push-pull design 


\section{Relevant Issues and Future Works}

\section{Performance Measure}

Performance measurement issues has recently appeared. It seems that assessing the performance and integration of closed-loop supply chain is becoming more important, as well as the impacts to the environment and ultimately for sustainable development.

Mondragon et al. [38] proposed a measures for CLSC, the purpose of the research are (a) to develop performance measures that can be used to provide an accurate diagnosis of the state of the supply chain by addressing both its forward and its reverse components (b) to identify the level of existing integration between parties, as this has been associated with supply chain performance. The methodology used is gathering elements for performance measures from literature reviewed, then applying the proposed set of measures to a case (a European mobile phone network operator). Finally, the findings are (1) the proposed set of measures for auditing purposes provide an overall picture of the performance of a closed-loop supply chain by revealing high levels of stock for the products analyzed, (2) there is a consequence of the difficulty to generate accurate forecasts and the accumulation of high quantities of product prior to launch.

Olugu and Wong [39] proposed an expert fuzzy rulebased system for closed-loop supply chain performance assessment in the automotive industry, while Paksoy et al. [40] proposed operational and environmental performance measures in a multi-product closed-loop supply chain.

\section{The Use of Sensor Technology}

Uncertainty is inevitable in a closed loop supply chain due to the unknown quantity and quality of returns that can influence the overall network, forward as well as reverse channel. However, the efforts to tackle this problem were limited and recently have shifted to technology innovation to minimize the source of uncertainty of product returns, rather than capturing the uncertainty by means of stochastic models that usually significantly increases complexity of the problem. Identification tools such as RFID tags and SEPs were considered in some papers, such as (Visich et al., [41]) who proposed that RFID can be effectively used to help decision making during the return process and to enhance value recovery. As the RFID system cost decreases and standards become clearer, it has become a promising tools to provide solutions in managing product returns across the entire supply chain. Also, Ilgin and Gupta [42] proposed the implementation of Sensor embedded products (SEPs) to improve reverse or closed loop supply chain system performance, related to high level of uncertainty associated with the disassembly yield due to non-functional and/or missing components.

Lee and Chan [43] tried to to determine collection centers that minimize the reverse logistics costs and use RFID to count the quantities of collected items in collection points and send the signal to the central return center for vehicle scheduling.

\section{Knowledge Sharing in CLSC}

Knowledge Management is one important part of an organization. The process of obtaining knowledge was described by Nonaka [44] in five interrelated phases. The first phase is to share tacit knowledge, which it is not directly available for the general organization of tacit knowledge held by individuals and obtained primarily from experience and not easily expressed in words. In contrast to the explicit knowledge that can usually be expressed among others by manual procedures, work documents, or images and data, tacit knowledge requires a more complicated business. This is influenced by emotions, feelings and individual mental models that need to be shared in order to build mutual trust. Therefore, knowledge sharing becomes an important challenge to the success of the process of obtaining knowledge (knowledge capture).

In CLSC, the parties involved are connected in a network that includes suppliers, manufacturers, distributors, retailers, consumers in the chain to achieve progress, while the reverse chain parties involved are collector (this role can be carried out by the retailer, or the manufacturer's third party), manufacturer in the role of the recovery process, a distributor who distributes products of the recovery, and retailers to market recovery, as given in Figure 4.

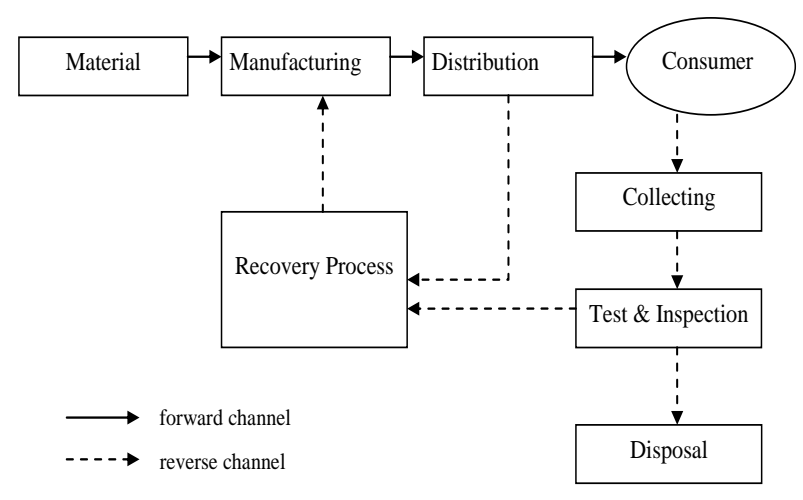

Figure 4. Closed-loop supply chain 
Characteristic aspects of knowledge for CLSC in the matrix Davenport [45], can be classified as a collaborative model, because the level of interdependence of the CLSC is high with the involvement of several parties in the circle process, while the complexity of the work is high because it requires interpretation and decisions that are primarily related to a number of uncertainties appears in the CLSC, such as demand uncertainty, variability of product returns, and degrees of recovery.

Because the process involves a cycle, CLSC supports the management in terms of efficiency, quality, and speed of service, innovation, and environmental impact. Those would be influenced by the knowledge of the product throughout its life cycle, which is described as follows:

Raw materials: knowledge of the properties of raw materials and treatment can improve the performance of the process of designing products and processes to streamline production and transporttation costs and speed of service manufacturer.

Process: knowledge of the production process from design to assembly would be beneficial for the distributor to arrange transport and capacity, which handles the maintenance and repair of the product (can be a distributor, retailer or a third party contracted), the collector during disassembly, recovery department as remanufacturing or recycling process, and the department that handles the waste production. Of course, there is still a lack of knowledge that can be shared, such as the components of innovative product design and superior, can not always be shared openly.

Early use: knowledge of how users use the product can be useful for the improvement of product design, increased efficiency of energy use in the active product, and an increase in environmentally friendly design. Similarly, for the collectors, knowledge about user behavior can facilitate the collection of the product at the end of the useful life (end of use) or at the end of its life cycle (end of life). For product recovery department, knowledge of the treatment of users of the product can streamline the recovery process.

End of life cycle: knowledge about the condition of the product will be beneficial to the department that handles the recovery process, knowledge of the handling of the product at the end of the useful life cycle of the product could help the design improvements, and the finance department to improve the valuation process. Knowledge of the recovery process will be useful for determining the selling price, distribution method, marketing strategies for the recovered product.
In the discussion above, the raw material suppliers do not benefit directly from the knowledge sharing, especially in the CLSC, where pure raw materials must be reduced. However, the other manufacturers still require the services of a supplier for the survival of the whole production. Therefore the benefits that can be gained by the suppliers are more focused on sharing tacit knowledge to increase productivity supplier industry itself, as has been done by Toyota.

Through the above description it can be concluded that in a CLSC, knowledge management is necessary because the performance of the supply chain as a whole can be improved.

\section{Management aspects: leadership, strategy and commitment}

In a CLSC, manufacturer generally has highest interest in the concept, because she naturally becomes the leader in knowledge sharing network CLSC (CLSC-KSN), though not necessarily so. Leaders must initiate the formation of the network that has a regular agenda, which can be done through real meetings and through cyberspace, and must have strong leadership to move. From the strategic aspects, for the network to be working as expected, it needs to have a common objective that benefits all members of the network, and further elaborated in the strategy for each party in the supply chain. As for the commitment-related problems, the network leader's commitment is vital, because it determines whether the knowledge sharing process works well or just a slogan

\section{Socio-technical aspects: infrastructure, infostructure and infoculture}

Infrastructure can be built with a web-social characteristics are flexible, in which all parties can access the knowledge that is needed without excessive restrictions or limitations. As an illustration: manufacturers put information and knowledge products such as specifications, handling, packaging information, how to perform maintenance and repairs, as well as the disassembly process. Other parties, such as retailers who act as a repair center can add knowledge about the kind of damage that often occurs and how retailers are handling it. All network members can comment and provide ideas or proposals repair, so that the exchange of knowledge occurs. Social Web can also be organized with good search facility, so that the knowledge stored easily found and accessed.

Infostructure of knowledge sharing using the social web will have the ability to capture tacit knowledge and make it explicit, because the social web is easy to 
use and it encourages discussion. In order for a structured exchange of knowledge occurs then the social web can be created by loading the formal and informal rules, as in the wiki.

\section{Conclusion}

In this paper we have described sustainable development and closed-loop supply chain, and how CLSC has a role as an agent of sustainable development.

Using the definition, description, and case studies from literature, we have argued that CLSC supports sustainable development in four way, i.e. (1) reducing the use of energy and mitigate emission problems, (2) reducing the use of natural resources, (3) mitigating the waste problems, and (4) supporting technology with environmental orientation.

We also proposed future works in CLSC that can further support the achievement of sustainable development.

\section{References}

1. WPP, World Population Prospects, the 2010 Revision, Available: http://esa.un.org/unpd/wpp/ Excel-Data/population.htm.

2. Graedel, T.E. and Allenby, B.R., Design for Environment. Prentice Hall, New Jersey, 1996.

3. CIA, CIA - The World Factbook, Available: https://www.cia.gov/library/publications/theworld-factbook/.

4. Kaebernick, H., Manmek, S., and Anityasari, M., Future Global Manufacturing, Are there Environmental Limits and Solutions?, in The International Manufacturing Leaders Forum (IMLF), Taiwan, 2006, pp. 1-11.

5. Tawaru, C., Hutan Surga Papua yang Semakin Terancam, Blog on Greenpeace Indonesia, 2011. [Online]. Available: http://www.greenpeace.org/ seasia/id/blog/hutan-surga-papua-yangsemakinterancam/blog/36462/.

6. Humas-UGM, Strategi Pengelolaan Banjir," Portal Akademik, Universitas Gajah Mada. Available: http://www.ugm.ac.id/index.php? page =rilisandartikel $=623$.

7. Prihandoko, Warga Jakarta Diajak Peduli Kelestarian Sungai., TEMPO.CO. Metro, 2011. Available: http://www.tempo.co/read/news/2011/ 05/13/057334278/Warga-Jakarta-Diajak-PeduliKelestarian-Sungai.

8. WECD, Our Common Future (The Brundtland Report). Oxford University Press, Oxford, 1987.

9. Guide, V.D.R.J. and van Wassenhove, L.N., Closed-Loop Supply Chains: An Introduction to the Feature Issue (Part 1), Production Operation Management, 15(3), 2006, pp. 345-350.
10. le Blanc, Closing Loops in Supply Chain Management: Designing Reverse Supply Chains for End-of-life Vehicles, Dissertation, Tilburg University, 2006

11. Lebreton, B., Strategic Closed-Loop Supply Chain Management, in Lecture Notes in Economics and Mathematical Systems 586, Springer Berlin Heidelberg, 2007, pp. 1-158.

12. Guide, V.D.R.J., Jayaraman, V., and Linton, J. D., Building Contingency Planning for Closedloop Supply Chains with Product Decovery, Journal of Operation Management, 21(3), 2003, pp. 259-279.

13. Krikke, H., Bloemhof-Ruwaard, J.M., and van Wassenhove, L.N., Concurrent Product and Closed-loop Supply Chain Design with Application to Refrigerators, International Journal of Production Research, 41(16), 2003, pp. 36893719.

14. leischmann, M., van Nunen, J.A.E.E., and Ben Grave, Integrating Closed-Loop Supply Chains and Spare-Parts Management at IBM, Interfaces (Providence), 33(6), 2003, pp. 44-56.

15. Kerr, W., and Ryan, C., Eco-efficiency Gains from Remanufacturing - A Case Study ofPphotocopier Remanufacturing at Fuji Xerox Australia, Journal of Clean Production, 9(1), 2001, pp. 75-81.

16. LG, LG Electronics Sustainability Report, 2008.

17. Seitz, M. A., A Critical Assessment of Motives for Product Recovery: The Case of Engine Remanufacturing, Journal of Clean Production, 15, 2007, pp. $1147-1157$.

18. Steinhilper, R., Remanufacturing - The Ultimate Form of Recycling. Fraunhofer IRB Verlag, 1998.

19. Franke, C., Basdere, B., Ciupek, M., and Seliger, S., Remanufacturing of Mobile Phones - Capacity ,Program and Facility Adaptation Planning, Omega, 34(6), 2006, pp. 562 - 570

20. Tong, B., Research on the Cell Phone Remanufacturing and Reselling, Dissertation, Erasmus University Rotterdam, 2006.

21. Chan, F.T.S., and Chan, H.K., A Survey on Reverse Logistics System of Mobile Phone Industry in Hong Kong, Managing Decision, 46(5), 2008, pp. 702-708.

22. Rathore, P., Kota, S., and Chakrabarti, A., Sustainability through Remanufacturing in India: A Case Study on Mobile Handsets, Journal of Clean. Production, 19(15), 2011, pp. 1709-1722.

23. Wang, J., Zhao, J., and Wang, X., Optimum Policy in Hybrid Manufacturing/ Remanufacturing System, Compututational Industrial Engineering, 60(3), 2011, pp. 411-419.

24. Xing, K., Belusko, M., Luong, L., and Abhary, K., An Evaluation Model of Product Upgradeability for Remanufacture, Internatioanl Journal of Advance Manufacturing Technolofy, 35(1-2), 2007, pp. 1-14. 
25. Kwak, M., and Kim, H., Market Positioning of Remanufactured Products with Optimal Planning for Part Upgrades, Journal Mechanical Design, 135, January, 2013, pp. 1-10.

26. Nnorom, I.C., and Osibanjo, O., Overview of Electronic Waste (e-Waste) Management Practices and Legislations, and Their Poor Applications in the Developing Countries, Resource Conservation Recycle, 52(6), 2008, pp. 843-858.

27. Neto, J.Q.F., and Bloemhof-Ruwaard, J.M., The Environmental Gains of Remanufacturing: Evidence from the Computer and Mobile Industry, ERIM Report Series in Management, ERS-2009024-LIS, Erasmus University, 2009

28. Nnorom, I.C., and Osibanjo, O., Overview of Prospects in Adopting Remanufacturing of Endof-Life Electronic Products in the Developing Countries, International Journal of Innovation and Management Technologi, 1(3), 2010, pp. 328-338.

29. Neto, J.Q.F., Walther, G., Bloemhof-Ruwaard, J. M., van Nunen, J.A.E.E., and Spengler, T., From Closed-loop to Sustainable Supply Chains: The WEEE Case, International Journal of Production Research, 48(15), 2010, pp. 4463-4481.

30. Neto, J.Q.F. and Bloemhof-Ruwaard, J.M., An Analysis of the Eco-Efficiency of Personal Computers and Mobile Phones, Production Operation Management, 21(1), 2012, pp. 101-114.

31. Lund, R.T., and Hauser, W.M., Remanufacturing - An American Perspective, in 5th International Conference on Responsive Manufacturing - Green Manufacturing (ICRM 2010), Ningbo, China, 1113 January 2010, 2010, pp. 1-6.

32. Gray, C., and Charter, M., Remanufacturing and Product Design, International Journal of Product Development, 6(3-4), 2008, pp. 375-392.

33. Kannan, G., Sasikumar, P., and Devika, K., A Genetic Algorithm Approach for Solving a Closed Loop Supply Chain Model: A Case of Battery Recycling, Applied Matematical. Model, 34(3), 2010, pp. 655-670.

34. Chung, C.J., and Wee, H.M., Short Life-cycle Deteriorating Product Remanufacturing in a Green Supply Chain Inventory Control System, International Journal of Production Economic, 129(1), 2011, pp. 195-203.
35. Guide, V.D.R.J., and van Wassenhove, L.N. Managing Product Returns for Remanufacturing, Production Operation Management, 10(2), 2001, pp. 142-155.

36. Jo, H., Yang, S., Kim, T., and Kim, H., ANPbased Reverse Logistics Model for e-Waste Management, POMS 21st Annual Conference, Vancouver, Canada, May 7-10, 2010.

37. Hsueh, C., An Inventory Control Model with Consideration of Remanufacturing and Product Life Cycle, International Journal of Production Economic, 133(2), 2011, pp. 645-652.

38. Mondragon, A.E.C., Lalwani, C., and Mondragon, C.E.C., Measures for Auditing Performance and Integration in Closed-loop Supply Chains, Supply Chain Management: An International Journal, 16(1), 2011, pp. 43-56.

39. Olugu, E.U. and Wong, K.Y., An Expert Fuzzy Rule-based System for Closed-loop Supply Chain Performance Assessment in the Automotive Industry, Expert Systems with Applications, 39(1), 2011,pp. 375-384.

40. Paksoy, T., Bektas, T., and Özceylan, E, Operational and Environmental Performance Measures in a Multi-product Closed-loop Supply Chain, Transportation Research Part E, 47, 2011, pp. 532-546.

41. Visich, J.K., Li, S., and Khumawala, B.M., Enhancing Product Recovery Value in Closedloop Supply Chains with RFID, Journal of Management Issues, 19(3),2007, pp. 436-452.

42. Ilgin, M.A. and Gupta, S.M., Performance Improvement Potential of Sensor Embedded Products in Environmental Supply Chains, Resources Conservation Recycle, 55(6), 2011, pp. 580-592.

43. Lee, C.K.M. and Chan, T.M., Development of RFID-based Reverse Logistics System, Expert Sistem and Application, 36(5), 2009, pp. 92999307.

44. Nonaka, I., The Knowledge-Creating Company, Harvard Business Review, Nov-Dec 1991.

45. Davenport, S., Exploring the Role of Proximity in SME Knowledge-acquisition, Resources Policy, 34(1), 2005, pp. 683-701. 